DOI: $10.20472 / T E .2020 .8 .1 .003$

\title{
MANAGERIAL COMPETENCIES AND EDUCATION NEED OF SCHOOL HEADMASTERS IN THE CZECH REPUBLIC
}

\author{
ROMANA LISNEROVA, JANA MARIE ŠAFRÁNKOVÁ, EVA URBANOVÁ
}

\begin{abstract}
:
The paper is focused on the analysis of managerial competencies and further education needs of headmasters of primary and secondary schools in the Czech Republic. The aim of the paper is to analyse selected competencies and activities of primary and secondary school headmasters with a focus on their work activities related to the management of teaching staff. The results of the analysis are based on the results of the authors' survey and on the secondary analysis of data from the Talis 2018 survey. The results show that in further education of managerial competencies of headmasters are mainly human resources, financial management, providing effective feedback, developing a career development program for teachers.
\end{abstract}

\section{Keywords:}

headmaster, elementary school, high school, lifelong learning, professional development

JEL Classification: J20, J24, J29

\section{Authors:}

ROMANA LISNEROVA, Department of Andragogy and Educational Management, Faculty of Education, Charles University, Czech Republic, Email: lisnerova@post.cz JANA MARIE ŠAFRÁNKOVÁ, Department of Andragogy and Educational Management, Faculty of Education, Charles University, Czech Republic, Email: janamarie.safrankova@pedf.cuni.cz EVA URBANOVÁ, Department of Andragogy and Educational Management, Faculty of Education, Charles University, Czech Republic, Email: eva.urbanova@pedf.cuni.cz

\section{Citation:}

ROMANA LISNEROVA, JANA MARIE ŠAFRÁNKOVÁ, EVA URBANOVÁ (2020). Managerial Competencies and Education Need of School Headmasters in the Czech Republic. International Journal of Teaching and Education, Vol. VIII(1), pp. 33-46., 10.20472/TE.2020.8.1.003 


\section{Introduction}

The paper is concentrated on the analysis of managerial competencies and further education needs of headmasters of primary and secondary schools in the Czech Republic. The aim of the paper is to analyses selected competencies and activities of primary and secondary school headmasters with a focus on their work activities related to the management of teaching staff. The research analysis is based on the results of the authors' survey on managerial competencies of headmasters' and on the secondary analysis of selected data in correlation with paper topic from the Talis 2018 survey. Further education of managerial competencies of headmasters' in paper is based on main soft skills as communication with school employees, human resources, providing effective feedback, developing a career development program for teachers.

\section{Literature review}

The school management or educational management is a part of management and term 'management' is now commonly used in the context of education in a variety of contexts. Most often it refers to a group of people who manage or run a school, they are the school head and his deputy, and it is also used to indicate a set of activities that this group of people performs and thus ensures the management and management of the school.

Managerial competences define Veteška, Tureckiová $(2008$, p. 80$)$ as the ability to successfully perform a function or set of functions.

At the same time, it sorts managerial competencies into several components:

- knowledge,

- traits,

- attitudes

- skills,

- experience,

- technical I competence,

- competence in dealing with people (Veteška, Tureckiová, 2008, p. 81)

Management and managerial activities depend on an organizational structure, that clearly defines the relationships between individual job positions, including management staff and is used to navigate the hierarchy of job positions within an organization. The organizational structure of the school is realistically simple, as it is always the headmaster, his deputy or two deputies depending on the size of the school and then the number of teachers. Other staff such as administration, maintenance and in most schools and kitchens there are only a few individuals.

The organizational structure is important for communication within the school, eventually also for ensuring communication and marking relations between a particular 
organization and the external environment. It is based on the thinking of managers about the whole company, school, etc. - to a certain extent, it is also a reflection of the behaviours, relationships and composition in a given company of people.

According to Mullins (1993), it is important to take the following into account when creating the organizational structure:

- clarification of intentions (in particular due to the division of employees into groups according to their duties and activities);

- tasks and essential elements of functions (helping to define structure relationships between individual employees and their positions);

- division of work and groups of people (helps to maintain balance between the different levels of the structure);

- centralization and decentralization (helping to set up activities that meet the needs of the organization with respect to deadlines and the organization as a whole);

- principles of organization (eg specialized positions, coordination of work, meaning or importance of individual functions - positions in the structure);

- Time span of the procedure (delimiting how many areas are controlled, whether the control is wider or narrower);

- formal organizational relationships (other links in the structure);

- liner and personnel organization (definition of department managers and specialists or additional support across all departments);

- project teams and organization matrices (this is a graphical representation of all areas, relationships and relationships considered) (Mullins 1993, pp. 310 - 335).

In addition, Jay\&Templar (2006) complements managerial skills, which they further classify according to the roles the manager gets into during his / her activity.

Thus, there are

- managerial skills as conducting interviews, evaluating staff, dealing with different types of people, working with a new employee and coaching,

- leadership skills as leading meetings, preparing projects, making decisions,

- skills as executors (work) budgeting, presentation skills, designing, negotiating and working with time).

Throughout the wide area of management, each manager, using his / her potential (skills, knowledge, experience), finds his / her practices and principles that help him / her to formulate development goals as well as engage people in individual activities leading to effective results. In order to be motivational for each employee, it is also necessary to start from his / her potential, his / her abilities, knowledge, skills, ie his / her competences. Competences in this case are defined as sets of knowledge, skills, attitudes and values needed to perform a particular activity (lurea,2017). Veteška, Tureckiová (2008) talks about competence management. They consider this approach to management to be very progressive, as they lead to the definition of 
professional competencies that will become company-specific, school. Such competences can then help managers to discover new employees, but also help selfreflection of employees, especially in their professional growth. The self-reflection of each employee is needed to formulate personal development goals that should be in accordance with the requirements of the company and thus with the professional competencies that the employees define together and then share them. The school most often evokes the environment in which education takes place. We can also mean school as a building or school in the sense of gaining new knowledge, experience.

It is precisely identifying the abilities of existing employees and putting emphasis on the necessary abilities of new employees that are essential for the manager's further work with them. However, it depends on how the manager will proceed in personnel activities. Each manager has his own approach to managing and leading people. Tyson, Jackson (1997) talks about managerial style and mentions various forms of leader's behaviour that directly influence that style. In the school environment, there is sometimes a distinction between top or top management and middle management. department - in the case of conservatories, heads of methodical associations or subject commissions, who are in charge of the management of a given area or subject or set of subjects and are responsible for all activities related to this area. The middle management group can also include department heads or school canteens.

Prücha (2002) states that E. L Thorndike, was concerned with the frequency of using school as early as 1927 and found that the word was among the first 1000 words with the most common occurrence in the language. Furthermore, from this finding, Prucha concludes that school is something so important in the life of an individual and society that it is constantly discussed (Průcha, 2002, p. 388).

The school, in connection with the topic of the article, can be perceived as an educational environment in which the educational processes take place. Educational processes are all activities of people in which learning occurs on the part of a subject, to whom a certain complex of information is exposed by some other subject or technical device (Průcha, 1995, p. 9).However, these are not only educational processes, but also managerial leadership processes. Self-evaluation processes are also necessary, thanks to which the school can develop. In connection with self-evaluation they mention Hrubá, Chvál et al. (2019) the importance of determining the purpose of self-evaluation and its communication within the teaching staff.

Ability and especially readiness of schools to obtain data through self-evaluation processes can significantly help in the planning of school's own development, taking into account changing conditions and changes that are expected by schools (Bolan, 1999).

In the system conception, the school is a relatively independent system conditioned only by its relation to its surroundings, it is able to objectively evaluate places and functions of all its elements depending on their importance, to discover and optimize 
system relations and thus achieve a synergic effect (Prášilová, 2010, p. 17). Vaclav Mertin (2017) says that the role of director is a permanent stress situation with a number of very collision points. He argues that the director is in schizophrenia of managerial-pedagogical role, thus increasing his work share compared to the teacher. The position of headmaster is of course irreplaceable in the management and management of the school. However, what is expected of school heads to ensure continuity of pre-school and primary education? What specific skills should they have and what specific activities they should perform, what processes to provide? There is no clearer expression in any of the available professional literature titles that would help school headmasters to manage and manage the merged workplace and answer these questions.

The headmaster is a director of school and leading teacher too whose work is diverse in practice and covers many areas (managerial, educational, psychological, legal, economic, human resources, etc.), which are governed in particular by the legislation with which he should be familiar. The only measurable information in the headmaster is the performance of direct teaching activity, i.e. the teacher's work. The content of this work is defined in the catalogue of works (Government Regulation No. 222/2010 Coll., On the Catalogue of Works in Public Administration, as amended), according to which directors are assigned to the 12th or 13th class.

The school headmasters' work includes comprehensive educational and educational activities related to the creation and ongoing updating of pedagogical documentation and individual educational plans; development of concepts for the development of educational fields; comprehensive educational activities in the system of further education of pedagogical staff connected with the creation of educational programs accredited in the system of further education of pedagogical staff and their evaluation; development of the concept of development of school educational programs; specialized methodological activities in the field of pedagogy and psychology; creation and coordination of international projects focused on education and training.

The competencies of managers of Czech schools include the following areas leadership (strategic thinking), managerial (organization development), professional, personal, social, management and evaluation of the educational process (Šafránková, Šikýř, 2018).

Another division of competences of school heads was brought about by the Individual National Project called Career System, within which the draft of the standard of the teacher and the school head was solved (MEYS, 2015). The Director's Standard covers the following areas of competence of school heads:

- guidance and management of education and training,

- leadership based on values and vision,

- leadership,

- management of the organization,

- personal and professional development. 
The Andragogical Vocabulary (Andromedia, 2016, online) describes the extended concept of key qualifications that originated in the 1980s - 1990s. The extension consists in the introduction of key competences and their brief characteristics. These are competencies that represent the skills and competences required for successful integration into study, work and personal life. Some of these competences can be used and described in more detail for the role of director of a merged kindergarten and elementary school.

These are mainly the competencies needed for planning, organizing, managing and evaluating processes that the school head implements in practice:

- Professional competences to carry out specific activities, which are acquired in particular during on-the-job training.

- Self-responsibility (participatory competence) should support self-guided learning and responsible work performance. Also, the ability to make decisions and take responsibility.

- Teamwork ability (social competence) - social behaviour and work, cooperation, communication in a certain team or group.

- Systemic (methodical) competence - understanding of cause-effect relationships, project and task organization, management ability.

- The reflexivity competence should stimulate a critical examination of one's own work with the aim of enhancing its quality and stimulating its ability to innovate. (Andromedia, 2016, online)

These skills need to be described and counted throughout HR management. Armstrong (2015) talks about the need to recognize human capabilities in the context of employee development and describes the entire competence-based approach to human resource management.

\section{Goal and Method}

The results of the analysis are based on the results of the authors' survey and the data comparison secondary analysis of data from the Talis 2018 survey. The aim of the paper is to analyses selected competencies and activities of primary and secondary school headmasters with a focus on their work activities related to the management of teaching staff. This part is secondary content analyses of research data.

The methodology for research of school management students opinions on headmasters managerial activities analyse is based on 10 semi-structured interviews and the results of selected questions from quantitative research using a questionnaire with 25 questions with a Likert scale, 15 open questions and 10 respondent identifications. The survey was carried out at the end of the winter semester of the academic year 2019/2020, a research survey was carried out among 70 students of the 1 st -2 nd year of the School Management program $(37+33)$ focused mainly on the 
evaluation of management practices, but there are 7 questions on headmasters managerial activities. After completing the practice in the given semester, students completed an assessment of the content, organization and instructor skills of the headmaster of the school where the practice took place, and at the end made selfreflection.

The purpose of the paper is comparing and discuss some parts of the analysis of the work of school headmasters by students of education management in terms of their theoretical knowledge, practical skills, management and human resources development potential.

The analyses show the agreement and differences between the results of the international survey and the reality in schools from the perspective of students who have completed these practices.

The research question is: What are the main management activities of the school and how do the opinions from the survey differ?

\section{Results and Discussion}

The school headmaster is a manager whose work activities are diverse in practice and cover many areas (managerial, pedagogical, psychological, legal, economic, human resources, etc.), which are governed mainly by the legislation that he should be familiar with.

The weekly scope of direct pedagogical activity in the Czech Republic is set by the school head by Government Regulation No. 75/2005 Coll. from the number of classes, departments, study groups, courses, educational groups, or children, pupils or students at school. There is an inverse proportion, the more of them, the less direct pedagogical activities the school head performs.

\subsection{Talis survey and managerial competencies of school headmasters}

In secondary data analyses was analysed one part of results concentrated to managerial competencies of Czech headmasters realised in Talis 2018. The International Teaching and Learning Survey TALIS 2018 is an international survey that provides teachers and headmasters with an opportunity to contribute to the analysis of education and educational policy. It is conducted under the guidance of the Organization for Economic Cooperation and Development (OECD). The TALIS survey focuses, among other things, on the management of schools, where it determines the representation of other persons in the school management who are involved in its management or development.

Is part of them:

- director 
- deputy director,

- chief

- economist

- representatives for the training of a particular field (eg for certain subjects or levels of education),

- teachers,

- school board,

- legal guardians,

- pupils.

Furthermore, TALIS examines the work activities of school headmasters, including:

- appointing or hiring teachers;

- temporary or permanent dismissal of teachers from employment,

- determination of the initial salaries of teachers, including the salary assessment,

- deciding to increase teachers' salaries;

- deciding on the use of funds from the budget within the school

- establishing principles for assessing pupil behavior and disciplinary measures;

- establishing principles for pupil assessment, including national or regional assessment;

- deciding on the admission of pupils to school,

- choice of teaching materials,

- determining the content of a subject or seminar, including school education programs and framework education programs;

- deciding on the offer of courses and seminars.

TALIS 2018 will build upon the success of the TALIS 2013 survey, which had a strong focus on school leadership, teachers' professional environment, teaching conditions and the impact on school and teacher effectiveness. The specific content of TALIS 2018 will be defined with participating countries through a priority rating exercise, with the possibility of including new indicators. It is expected that TALIS 2018 will have a similar content focus as TALIS 2013, and will investigate further:

- the quality of teachers' instructional practices and beliefs about teaching

- the learning environment: characteristics of teachers and schools

- the importance of school leadership

- examining teachers' professional practices and classroom environment

- the relevance of teacher education and initial education

- improving teaching through professional development, appraisal and feedback

- exploring the relevance of school climate, learning environments and relations with stakeholders

- teacher self-efficacy and job satisfaction: why they matter.

- teachers' openness to innovation in the classroom 
- issues related with equity and diversity in the classroom

When comparing the work activities of the school head determined by the legal regulations of the Czech Republic and the content of the questionnaire in the framework of the TALIS 2018 survey, it is clear that it is possible to compare internationally and even the school year. The main indicator is the size of the school, because the smaller the school, the fewer people involved in managing the school, and often the headmaster is at his own discretion. The monitored work activities with the time devoted to it include:

- administrative tasks and meetings,

- school management activities and meetings,

- activities and consultations aimed at the school curriculum and teaching;

- dealing with pupils,

- dealing with legal representatives,

- dealing with the local community of people or representatives of business or industry from the same municipality or region.

However, according to the responses of the school directors in the TALIS 2018 survey, Czech school directors deal most with administrative tasks and meetings during the school year, up to $40 \%$ of their time, compared to an average of $29 \%$ in 23 European countries. On the contrary, they devote only $15 \%$ of their time to counselling and teaching activities (which also include class observation, pupil teaching, teacher mentoring and professional training). This is an area of pedagogical leadership that is perceived as the most important form of activity by the school director. Interaction with the local community, pupils and parents takes the least time. On average, in 23 European countries, headteachers interact with pupils and parents up to a quarter of their working time, compared to $17 \%$ of headteachers in the Czech Republic.

On the contrary, the proportion of time devoted to administrative and school management meetings and meetings increased (50\% in TALIS $2013,61 \%$ in TALIS 2018)

Czech directors have an exceptionally high degree of autonomy in deciding on human resources, budgets, rules and procedures at school, as well as curricula and teaching. More than $90 \%$ of them said that they play a key role in deciding on the appointment or recruitment of teachers, dismissing teachers, setting salaries, using the school budget, raising teachers' salaries or admitting pupils to school.

The TALIS 2018 survey also followed selected aspects of the so-called system leadership, ie various actions or initiatives aimed at strengthening relations between the schools and the communities in which they operate, in particular cooperation with school heads. In the pedagogical literature, the school's relations with the community and its cooperation with other schools are of increasing importance, since in some contexts their positive link with the development of the school has been demonstrated; 
it also introduces a new, less hierarchical approach to leadership for executives (see TALIS 2018 Conceptual Framework for more details). Participation in selected systemic management activities is the least frequented by the headmasters of schools involved in the TALIS survey (compared to other activities of pedagogical or administrative leadership) also from an international perspective, but the Czech Republic is the EU with the lowest proportion of headmasters in the EU often "cooperated with headmasters of other schools on difficult tasks" (18\% in the Czech Republic, 38\% in the EU). In all countries involved in TALIS 2018 reported.

\subsection{Authors' research}

On the basis of the research it was found out that practical preparation of students of the study program School Management in the form of managerial practices at departmental schools is a beneficial and important part of the study. Students' knowledge gained in the winter semester of the academic year 2019/2020 in the practical part of the study reflects its theoretical part, and departmental schools allow students to become acquainted with selected activities of the school head in an authentic school environment.

Obtained results of hedmasters'activities evaluation by students:

Strategic management:

1. creation of strategic documents,

2. responsibility for the implementation of educational programs,

3. ensuring that the school runs economically,

4. ensuring the publicity of the school,

5. creation of a system of evaluation and remuneration of employees.

Operational management

1. searching for financial resources beyond the state budget and the budget set by the founder (grants, projects, sponsorship),

2. setting up a training plan for each employee (career development plan),

3. review of pedagogical documentation,

4. preparation for educational meetings,

5. studying legislation,

6. distribution of tasks and deadlines;

7. leadership,

8. delegating work to other employees

9. representing the school in negotiations with legal guardians, social partners, founder, authorities, etc.,

10. appointment of deputy headmasters and other authorized persons,

11. quality control of work (observation) and observance of work obligations,

12. operative solution of the problem, 
13.solving tasks according to the current situation and importance, 14. decision-making in the admission procedure.

Personal management:

- recruiting and motivating employees to implement strategies;

- ensuring the adaptation of new employees (creation of a manual),

- ensuring sufficient qualified teaching staff

Teaching:

- educational and educational activities.

Administration:

- setting the school budget,

- set how information and documents are shared with other colleagues.

- keeping school documentation

The research survey among school management students opinions showed that due to many duties, which are not even defined in the scope of work, headmasters are burdened with such time that they often do not have time for obligatory direct pedagogical activity which they have as one of their work activities given by legislation. The worst situation is in small schools where there is no one to whom to delegate selected work activities.

\section{Conclusion}

The results of research results and comparison of Talis data on work activities show that in the managerial competencies of headmasters, particular emphasis should be placed on developing cooperation between teachers, human resource management, financial management, providing effective feedback and developing a career development program for teachers. Unlike companies that often have different managers for each area of their activity, the school headmaster is often alone and has to deal with many unexpected situations. The headmaster performs functions as a teacher, employer, economist, lawyer, psychologist, human resources officer and is responsible for the smooth running of the school, which consists mainly in ensuring the teaching and education in terms of personnel and content. They must manage and lead people, communicate, decide on the use of funds, seek additional financial resources, evaluate and reward employees and, last but not least, carry out direct pedagogical

In accordance with legal regulations, the school headmaster performs the following work activities: 
- direct teaching activities,

- comprehensive educational and educational activities,

- creation of concepts,

- comprehensive educational activities in the system of further education of pedagogical staff,

- development of the concept of development of school educational programs

- making decisions on all matters relating to the provision of education and school services;

- responsibility for using state budget funds

Furthermore, the following activities of the school head are monitored in the Czech Republic in the framework of international surveys:

- recruitment / dismissal of teachers,

- teachers' salaries, deciding on the use of funds from the budget within the school;

- establishing principles for assessing pupils;

- deciding on the admission of pupils to school,

- choice of teaching materials,

- determining the content of a subject or seminar, including school educational programs and framework educational programs.

In the research of the author, the students of the School Management study program lean towards work activities that are related mainly to ensuring the proper operation of the school. educational and educational activities,

- ensuring sufficient qualified teaching staff,

- ensuring the school run economically (budget)

- seeking additional financial resources beyond the budget (grants, projects, sponsorship);

- ensuring the capacity of the school,

- ensuring the publicity of the school,

- delegating work activities to other employees, if possible,

- solving tasks according to the current situation and importance,

- representing the school in negotiations with legal guardians, social partners, founder, authorities, etc.,

- quality control of work (observation) and observance of work duties.

The results show that in the continuing education of headmasters, particular emphasis should be placed on developing cooperation between teachers, human resource management, financial management, providing effective feedback and developing a career development program for teachers. 
Of course, the school head can delegate selected work activities to other staff, but he will always be responsible. In small schools, however, there is often no one to delegate to. Unfortunately, the high level of school autonomy in the Czech Republic is often a problem for school headmasters, because in practice there are often conflicts with legal regulations that do not correspond to the real situation in education. On the other hand, the school head is often affected by the school headmaster to a high degree of competence.

From the perspective of future student management, the results of the authors' research support the assumption that students in education management gained experience during their studies during this professional practice.

For further research, the author will focus on monitoring the work activities of school headmasters in the Czech Republic.

Acknowledgment

The paper is a partial output of the project of the Faculty of Education of Charles University, Czech Republic, called Progress Q17 (2017-2021): The Teachers Preparation and Profession in the Context of Science and Research.

\section{References}

Armstrong, M., Stephen, T. (2015) Řízení lidských zdrojů - Moderní pojetí a postupy. 13. vyd., Praha: Grada publishing. ISBN 978-80-247-5258-7.

Bolam, R. Educational Administration, Leadership and Management: Towards a Research Agenda. BUSH, Tony, Les BELL, Ray BOLAM, Ron Glatter a Peter Ribbins. Educational Management: Redefining Theory, Policy and Practice [online]. 1 Oliver's Yard, 55 City Road, London EC1Y 1SP United Kingdom: SAGE Publications, 1999, s. 192-205 [cit. 2019-08-08]. DOI: 10.4135/9781446219676.n15. ISBN 9780761965558. Available from: http://sk.sagepub.com/books/educational-management/n15.xml

Federičová, M. (2019). Mezinárodní srovnání ředitelů škol: české administrativní inferno. Praha: Národohospodářský ústav AV ČR. ISBN 978-80-7344-506-5

Hrubá, J. \& M. Chvál, 2019. Na cestě ke kvalitní škole. Praha: Wolters Kluwer. ISBN 978-807598-392-3.

Iurea, C. The Role of the Manager in the Succes of School Organizations [online]. In: 2017-524, s. 188-193 [cit. 2019-08-08]. DOI: 10.15405/epsbs.2017.05.02.25. Available from: http://www.futureacademy.org.uk/files/images/upload/25.\%20EduWorldF\%202017.pdf

Jay, R. \& Templar, R. (2007). Velká kniha manažerských dovedností. Praha: Grada Publishing. ISBN 80-247-1279-2.

Mertin, V. (2017). Ředitel = funkce na dobu přechodnou. Řízení školy: Letní speciál, s. 40-41. Wolters Kluwer. 
Mullins, L., J., 1993. Management and organizational behaviour. Third edition. London: Pitman Publishing. ISBN 0-273-60039-7.

MŠMT (2015). Kariérní systém. Praha: Národní institut pro další vzdělávání.

Lazarová, B., Pol, M. \& Sedláček, M. (2015). Mezinárodní šetření TALIS 2013. Souhrnná zpráva mapující pedagogické vedení ředitelů základních škol v ČR. Praha: ČŠı.

OECD (2019). TALIS 2018 Results (Volume I): Teachers and School Leaders as Lifelong Learners, TALIS, OECD Publishing, Paris.

Průcha, J. (2002). Moderní pedagogika. Praha: Portál. ISBN 80-7178-631-4.

Průcha, J. (2017). Vzdělávací systémy v zahraničí. Praha: Wolters Kluwer. ISBN 978-80-7552845-2.

Průcha, J. \& Veteška, J. (2014). Andragogický slovník. (Andragogical Dictionary) 2. Ed. Praha: Grada Publishing.

Prášilová, M. (2010). Školský management: studijní texty pro distanční vzdělávání. Olomouc, Univerzita Palackého. ISBN 978-80-244-2574-0.

Šafránková, J. M., \& Šikýř, M. (2018). Responsibilities and competencies in personnel management at Czech schools. Oeconomia Copernicana, 9(3), 529-543. doi:10.24136/oc.2018.027 Available from: http://economicresearch.pl/Journals/index.php/oc/article/view/1054

Tyson, S. \& Jackson, T. (1997). Organizační chování. Praha: Grada Publishing. ISBN 807169-296-4.

Veteška, J. \& Tureckiová, M. (2008 a). Kompetence ve vzdělávání. (Competences in education). Praha: Grady Publishing. ISBN 978-80-247-1770-8.

Veteška, J. \& Tureckiová, M. (2008 b). Vzdělávání a rozvoj podle kompetencí. Praha: Univerzita Jana Amose Komenského. ISBN 978-80-86723-54-9.

Veber, J. et al. (2000). Management. Základy, prosperita, globalizace. Praha: Management Press. ISBN: 80-7261-029-5.

MANAGEMENT MANIA [online]. ISCED (International Standard Classification of Education). Copyright (C) 2011 - 2016 ManagementMania.com. [online, cit. 2018-09-12]. Dostupné z: https://managementmania.com/cs/isced-international-standard-classification-ofeducation 